УДК $577.114 ; 663.45$

\title{
Mannan: structure, biosynthesis, and methods extraction from yeast Saccharomyces cerevisiae
}

\author{
R. HARBAH ${ }^{1}, D$. Sc. T. V. MELEDINA ${ }^{1}$, D. V. MANSHIN ${ }^{1}$, V. V. ANDREEV ${ }^{2}$ \\ ${ }^{1}$ ITMO University \\ ${ }^{2}$ Baltika Breweries \\ E-mail: tatiana.meledina@yandex.ru
}

In recent decades, interest in biologically active Mannan-oligosaccharides isolated from yeast, algae, and higher plants have grown. The growth is due to their attractive properties, which have expanded their use and application not only in the food industry but also in medicine and animal feed. Indeed, the yeast extracts sector generates an enormous amount of yeast cell wall (YCW) as a by-product, so increasing attention is being paid to the yeast cell wall (YCW) as a promising source mannan. This review presents various sources of mannan and its structure and highlights the biosynthesis of mannan in S. cerevisiae yeast and its extraction methods.

Keywords: Mannan-oligosaccharides, yeast cell wall, biologically active, glycosylation.

Article info:

Received 12/11/2020, accepted 17/02/2021

DOI: $10.17586 / 1606-4313-2021-20-1-59-65$

Article in English

For citation:

Harbah R., Meledina T. V., Manshin D. V., Andreev V. V. Mannan: structure, biosynthesis, and methods extraction from yeast Saccharomyces cerevisiae. Journal of International Academy of Refrigeration. 2021. No 1. p. 59-65.

DOI: $10.17586 / 1606-4313-2021-20-1-59-65$

\section{Маннан - структура, биосинтез и методы экстракции из дрожжей Saccharomyces cerevisiae}

\author{
Р. ХАРБА ${ }^{1}, \partial-p$ техн. наук Т. В. МЕЛЕДИНА ${ }^{1}$, Д. В. МАНЬШИН ${ }^{1}$, В. В. АНДРЕЕВ ${ }^{2}$ \\ ${ }^{1}$ Университет ИТМО \\ ${ }^{2} О О О$ «Пивоваренная компания «Балтика» \\ E-mail: tatiana.meledina@yandex.ru
}

В последние десятилетия наблюдается высокий интерес к маннанолигосахаридам, выделенным из дрожжеей, водорослей и высших растений, что обусловлено их биологически активными свойствами, которые позволяют использовать данный полисахарид не только в пищевой промышленности, но также в медицине и кормах для животных. При этом сектор дрожжевых экстрактов в качестве побочного продукта производит огромные количества дрожжевых клеточных стенок, которые являются многообещающим источником маннана. Основное внимание данного обзора уделено основным источникам маннана, его структуре, биосинтезу в дрожжжевой клетке S. cerevisiae, а также методам экстракции.

Ключевые слова: Маннанолигосахариды, дрожжевая клеточная стенка, биологическая активность, гликозилирование.

Информация о статье:

Поступила в редакцию 12.11.2020, принята к печати 17.02.2021

DOI: $10.17586 / 1606-4313-2021-20-1-59-65$

Язык статьи - английский

Для цитирования:

Harbah R., Meledina T. V., Manshin D. V., Andreev V. V. Mannan: structure, biosynthesis, and methods extraction from yeast Saccharomyces cerevisiae // Вестник Международной академии холода. 2021. № 1. С. 59-65.

DOI: 10.17586/1606-4313-2021-20-1-59-65

\section{Introduction}

Mannan is a polysaccharide widely distributed in nature, formed from mannose residues linked by $\beta$ [1]-[4] bonds. It is obtained from various sources, such as plants, bacteria, fungi, and yeast. In nature, mannan generally is associated with other sugars, including galactose and glucose, so there are distinct forms generally recognized depending on the relative amounts of the additional sugars 
such as glucomannan, galactomannan, and glucogalactomannan.

Mannan polysaccharides have many attractive properties, such as biological activity, non-toxicity, rare adverse side effects, and this made it a focus of interest by various sectors [1]. In this context, many studies have shown the successful use of mannan as a biologically active substances in medicine and, even more, on the use of mannan as additives in the food industry and animal feeding. Studies have shown the importance of mannan in enhancing the immune system and suppressing the pathogens and its importance in improving the digestive system's health and thus improving growth performance and health [2, 3].

Recently there is an increasing focus on the mannan extracted from the yeasts for two essential reasons: Firstly, the yeast extracts sector produces a significant amount of (YCW) as a by-product, and secondly, yeast cell walls are cheap, so using them as raw material to extract mannan is a right choice [2]. Most of the yeast mannan is localized in the cell wall and is bound to the mannoprotein's protein complex. This type of mannan has an $\alpha-(1-6)$ linked to the main chain, and $\alpha-(1-2)$ and $\alpha-(1-3)$ linked branches. Mannan, obtained from the yeast cell wall, inhibits colonization of pathogenic bacteria in the gut $[4,5]$.

Besides, the mannan obtained from yeast is used as additives, both for human and animal feed, to prevent diarrhea [3]. Similarly, many studies reported improved performance, gained bodyweight and reduced mortality rates for birds fed on the mannan oligosaccharides containing diet $[6,7]$. In the food industry, mannan's antioxidant properties have expanded its application as antioxidant additives in food products [1]. Besides, mannan polysaccharide derived from yeast acts as prebiotic, where the addition of mannan extracted into yogurts has increased the viability of probiotic bacteria [8].

\section{Mannan sources}

Mannan is a polysaccharide mainly consisting of D-mannose. In most cases, mannan is found along with other sugars, such as glucose and galactose. Mannan is obtained from various sources. In plants, it plays a storage function as a reserve carbohydrate in seeds and vegetative tissues.

It has a structural role since it is involved in the construction of hemicellulose, representing about $23-32 \%$ of plants' polysaccharide composition. Therefore, mannan with cellulose and lignin are the main components of plants [9]. Besides its structural role and functions as a reserve carbohydrate, mannan, which is found as a constituent of some plants' cell walls like fern roots, has a defense mechanism that limits the bacterial ingress [10]. Hemicellulose, which contains mannan and heteromannan, is widely available in biological waste from agricultural residues such as grass, coffee bean extracts, and palm Kernel [11]. In addition to plants, fungi and algae are also a common resource for mannan, where the Dasycladalean alga Acetabularia acetabulum has long been known to contain mannan-rich cell walls [12].

Furthermore, Mannan polysaccharide is the main compound in the yeast cell wall, consisting of three significant compounds: mannan, $\beta-(1,3 ; 1,6)$-glucan, and chitin [13]. Since the yeast production sector produces a large amount of cell wall as a by-product and in addition to its low price, there is an increased interest in the yeast wall as a promising source for man- nan extraction $[13,16]$. Some studies have pointed out the importance of mannan of pathogenic Candida species because of its role in adhesion to epithelial cells and pathogenicity development. Therefore, investigation of the chemical structure of Candida mannan is necessary to understand the mechanism of pathogenicity and to develop new antifungal drugs [14, 15].

In Saccharomyces cerevisiae, mannan is localized in the outer layer of the cell wall and plays an essential role in determining the yeast's surface properties. Most of the mannan is associated with protein in mannoprotein, which represents $30-40 \%$ (by weight) of the total cell wall [17]. The mannan oligosaccharide (MOS) obtained from yeast reduces pathogenic bacteria such as Salmonella, E. coli, and Campylobacter because it attaches and adsorbs those bacteria [18]. Therefore, it inhibits their colonization in the intestines. Moreover, (MOS) can be a prebiotic, and it is a source of nutrients for the growth of some beneficial bacteria in the colon [2]. Besides the fact that mannan is considered to be the main component of the cell wall, the yeast can produce and release it into the culture medium. During the yeast cultivation in a sucrose-containing medium, the yeast Rhodotorula acheniorum $M C$ released $6.2 \mathrm{~g} / 1$ of mannan into the medium after 96 hours of cultivation, while the yeast Sporobolomyces salmonicolor $A L 1$ produced only $5.6 \mathrm{~g} / 1$ of glucomannan after five days of cultivation $[19,20]$.

In addition to fungi, algae, and yeast, some reports demonstrate some bacteria's ability to produce mannan, such as the gram-negative bacterium Pseudomonas syringae $p v$. ciccaronei, which produces mannan exopolysaccharide.

This polysaccharide consisted of the main chain of $\alpha$-(1, 6)-linked mannopyranose units with $80 \%$ substituted at C-2 by mono-, di- and trisaccharide side chains. Mannan exopolysaccharide, produced by the gram-negative bacterium Pseudomonas syringae pv. ciccaronei has phytotoxic effects, and it is the pathogenic agent responsible for the leaf spots of carob plants [21].

It has also been reported that two water-soluble polysaccharides have been isolated from marine bacteria Edwardsiella tarda. The polysaccharides consist of $\alpha-(1,3)$-linked mannose residues and branched mannose linkages. These polysaccharides have good antioxidant activity, which has expanded their use in the food industry [22].

\section{Structure of mannan}

Mannan polysaccharide is the main component of hemicellulose. In nature, it exists as a relatively pure mannose polymer $(>95 \%)$ or is generally associated with other sugars, such as glucose and galactose. Accordingly, the mannan is classified into four groups according to the compounds that enter in this polymer's composition, including the linear mannan that composed of mannose units joined together by $\beta$-(1-4)-links (fig. 1, a), glucomannan, galactomannan, and glucogalactomannan.

Mannan is the main component of hemicellulose. In nature, it exists as a relatively pure mannose polymer ( $>95 \%)$ or is generally associated with other sugars, such as glucose and galactose. Accordingly, mannan is classified into four groups, including the linear mannan that consists of mannose units joined together by $\beta$-(1-4)-links (fig. 1, a), glucomannan, galactomannan, and glucogalactomannan.

Glucomannan is a heteropolymer composed of $\beta$-(1-4)linked D-mannose and D-glucose monomers (fig. 1,b). Glu- 
comannan is a significant constituent in hardwood (angiosperm) and softwood (gymnosperms).

Hardwood glucomannan consists of mannan and glucan in a 2:1 ratio, respectively, without side groups, while softwood mainly consists of galactoglucomannan and glucomannan (which consists of 3:1 mannose and glucose residues, respectively, with the side group).

Galactoglucomannan contains mannose, glucose, and galactose residues in a ratio of $3: 1: 1$, respectively, where the galactose residue is associated with approximately every 15 th or 30th unit of mannose in position C6 or with glucose in position $\mathrm{C} 3$.

Glucomannan is extracted from grass and grains such as rice and wheat, a minor compound of aleurone and endosperm surface layer in grains. Glucomannan is also obtained from Konjac plants' roots (Konjac plant or elephant yam, which is native to the warm and tropical parts of Asia), which raw roots contain 10-8\% glucomannan. Glucomannan isolated from these plants is characterized by its ability to form a gel, which is affected by sugar and salt concentration. Gelatination is enhanced by sugar and inhibits by salt. This can be used to control its gelling ability in foods. Glucomannan is used as a substitute for fat in dairy and meat products [24].

Galactomannan is a hetero-polymer consisting of a $\beta-1,4-$ linked D-mannose chain with D-galactose side groups (fig. $1, c)$. Galactomannans are obtained from various sources, such as fenugreek seeds (containing $45-60 \%$ of galactomannans), guar gum, and carob trees [26]. Moreover, galactomannans are the main component of the cell wall of Aspergillus and Penicillium species [25]. Galactomannan is used as a food thickener because of its high viscosity. It is also considered an important dietary fiber that can reduce glucose absorption from the small intestine [26].

Galactoglucomannan is similar to glucomannan, which consists of $\beta$ - (1-4)-linked D-mannose and D-glucose monomers, except it has galactose side groups which are attached to either mannose or glucose [23] (fig. 1,d). Galactoglucomannan is obtained from softwood. Some studies indicate the probiotic properties of galactoglucomannan, which may expand their application as a dietary supplement in animal feed. Re- search data showed the beneficial nutritional properties of additional Galactoglucomannan in dog food [27, 28].

\section{Structure and biosynthesis of $\boldsymbol{S}$. cerevisiae cell wall mannan}

S. cerevisiae cell wall mannan consists of $50 \alpha-1,6$-linked mannoses main chain of, to which many branches consisting of $\alpha-1,2$ - linked and $\alpha-1,3$-linked mannoses are attached. These macromolecules bind to asparagine in proteins. Also, mannan has short oligomannoside units with $\alpha-1,2$ and $\alpha-1,3$ bonds that bind to serine or threonine in the protein $[12,31]$.

Mannan may attach to protein by two ways either via the nitrogen atom on the side chain of asparagine (N-linkage) or via oxygen atom on the serine's side chain threonine (O-linkage).

Thus, the O-linked structures are chains of 4-5 mannoses attached to serines or threonines, whereas the N-linked glycans comprise the core structure to which can be attached an outer chain structure of up to 200 mannose residues (Fig. 2).chain also contains several mannosylphosphatet give the oligosaccharides a negative charge $(26,32)$.

The synthesis of mannoprotein in yeast is a multi-stage process, including the association of the protein with chain (glycosylation) and the synthesis of a polysaccharide chain, which contains mannose residues obtained from the respective donors. All synthesis steps are carried out using glycosyltransferases suitable for each step $[35,36]$.

The individual stages of biosynthesis are localized in different cellular structures. Starting in the endoplasmic reticulum (ER), continue in the Golgi apparatus, and end the plasma membrane [36].

In yeast, glycosyltransferases involved in mannoprotein biogenesis use nucleotide sugars such as Uridine diphosphate glucose (UDP-Glc), Uridine diphosphate $\mathrm{N}$-acetylglucosamine (UDP-GlcNAc), GDP-Mannose (GDP-Man), dolichol phosphate mannose (Dol-P-Man), or dolichol phosphate glucose (Dol-PGlc) as donors [29, 37]. GDP-Man is formed from Fructose-6-Phosphate by the sequential actions of phosphomannose isomerase, phosphomannomutase, and GDP-Man pyrophosphorylase. Loss of any of these enzyme activities leads to severe glycosylation and secretion defects [29].

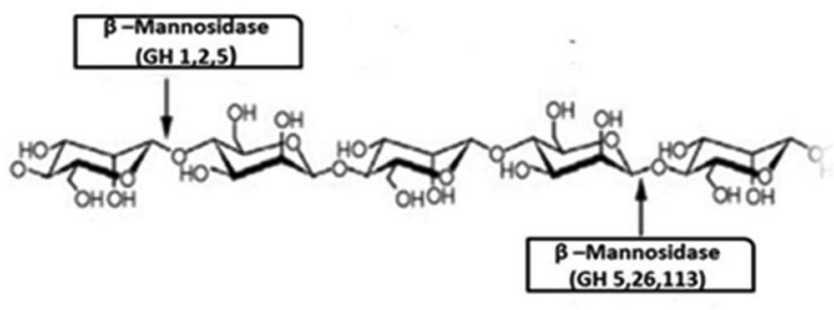

$a$

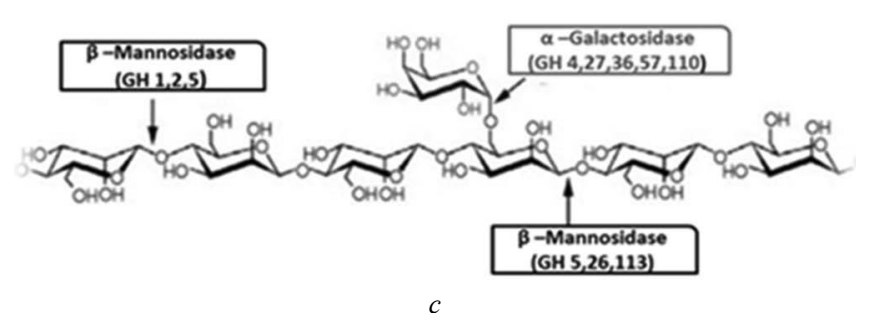

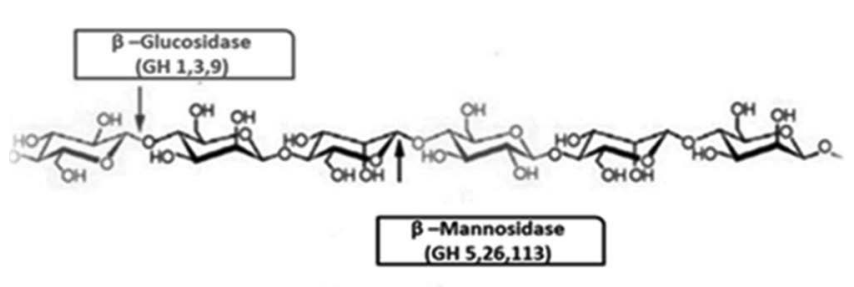

$b$

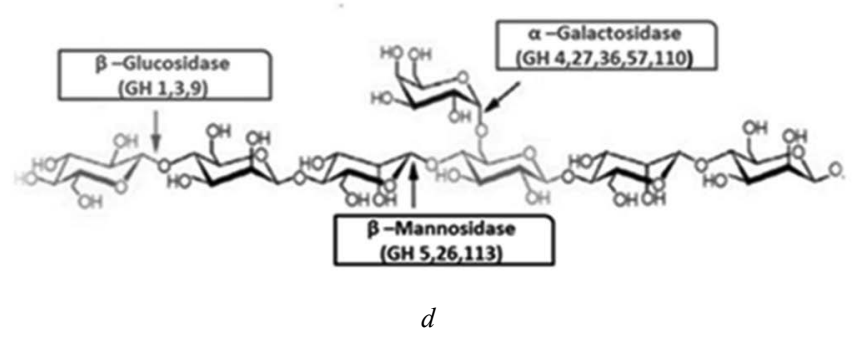

Fig. 1. Types of mannan: $a$ - linear mannan; b-glucomannan; $c$ - galactomannan; $d$ - galactoglucomannan [45] 


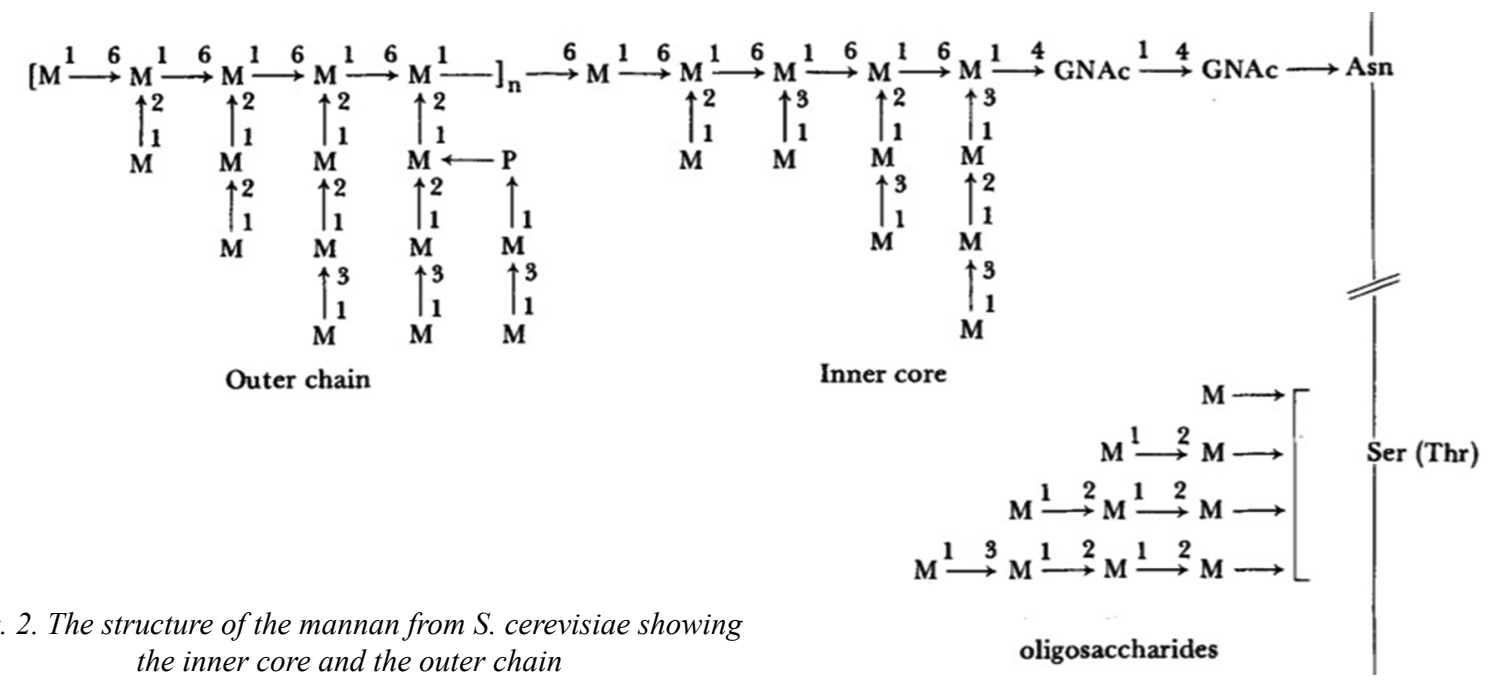

Dolichol, a product of the mevalonate pathway, plays a major role in the co-translational modification of proteins, which is known as $\mathrm{N}$-glycosylation. In yeast, dolichols contain 14-18 isoprene units (2-methyl-1, 3-butadiene, which has the formula $\mathrm{CH} 2=\mathrm{C}(\mathrm{CH} 3)-\mathrm{CH}=\mathrm{CH} 2)$.

Biosynthesis of dolichol starts with an extension of transfarnesyl diphosphate (FPP) by sequential addition of cis-isoprene units by the cis-prenyltransferases Rer2 and $\mathrm{Srt}^{1}{ }^{1}$, and this leads to the formation of a dehydrodolichyl diphosphate [29]. Then dehydrodolichyl diphosphate subsequently undergoes the loss of both phosphate groups by unknown enzymes, resulting in a polyprenol. Finally, the $\alpha$-isoprene unit of the polyprenol is then reduced by polyprenol reductase, Dfg10, and this saturated polyprenyl alcohol is known as dolichol. Then dolichol is phosphorylated by the CTP-dependent Dol kinase (Sec59), which catalyzes the terminal step in dolichyl monophosphate (Dol-P) biosynthesis [29, 36].

\subsection{Protein glycosylation}

Proteins can be modified by the addition of carbohydrate components to form glycoproteins, and this process is called glycosylation. Glycoproteins are important biomolecules that play an important role in the cell and can be found mainly in cell membranes [29].

\subsubsection{N-linked glycosylation}

$\mathrm{N}$-linked glycosylation begins in the endoplasmic reticulum (EP) and is completed in the Golgi apparatus [31].

As a first step, the Dol-PP-GlcNAc $\mathrm{Man}_{5}$ is formed on the ER membrane's cytoplasmic face and translocated into the EP membrane's luminal side. Then, Dol-PPGlcNAc $\mathrm{Man}_{5}$ is extended by four Man and three Glc on the luminal side of the ER membrane using Dol-P-Man and Dol-P-Glc as donors. As a result, GlcNAc $\mathrm{Man}_{9} \mathrm{Glc}_{3}$ is formed, which is transferred by the luminal oligosaccharyltransferase (OST) to an asparagine residue Asn-X-Ser/Thr sequons, where $\mathrm{X}$ can be any amino acid except proline [30, 32, 36]. GlcNAc $\mathrm{Man}_{9} \mathrm{Glc}_{3}$ (Glc: glucose, Man: mannose, GlcNAc: N-acetylglucosamine) is trimmed in the EP before its export the Golgi apparatus to glycans, which are recognized by the mechanisms that monitor a protein-fold-

1 https://www.yeastgenome.org/locus/S000004707 ing quality [33]. Correctly folded proteins are exported from the ER to the Golgi apparatus. The trimming occurs by removing $\alpha 1,2$-linked Glc using glucosidase I, and two $\alpha 1,3$-linked Glc using glucosidase II, and then $\alpha 1,2-$ linked Man using mannosidase I, respectively to form GlcNAc $\mathrm{Man}_{8}$ [36].

Glycoproteins are extended in the Golgi apparatus with a Mannan ${ }_{10-14}$ core-type structure or with mannan outer chains, which contain up to 200 mannose residues. The Golgi Mannosyltransferase complex transfers the mannose units from GDP-Man [29, 31].

Synthesis of yeast mannan's backbone occurs in the cis-Golgi, where the formation of core begins when a single $\alpha-1,6$-linked mannose residue is transferred by the Mannosyltransferase $(O c h l)$ to $\alpha-1,3$-linked mannose residue of the $\mathrm{Man}_{8} \mathrm{GlcNAc}_{2}$ structure. The elongation of the mannan backbone is carried out by the action of two cis-Golgi mannose polymerase complexes (Man-Pol I and Man-Pol II). An attractive advantage of these complexes is that they possess Mannosyltransferase activity and act sequentially to lengthen mannan's main chain. Man-Pol I complex contains proteins Mnn9 and Van1, whereas Man-Pol II complex contains proteins Anp1, Hoc1, Mnn9, Mnn10, and Mnn11 [29, 36].

The elongation process is continued by adding the first $\alpha-1,6$-linked mannose residue to the Och1-derived N-glycan $\left(\mathrm{Man}_{9} \mathrm{GlcNAc}_{2}\right)$ using Mnn9, after which 10-15 $\alpha$-1,6-linked mannose residues are added using Van1. Then the $\alpha-1,6$ backbone is extended with 40-60 $\alpha$-1,6-linked mannose residues using the M-Pol II complex. The $\alpha-1,6$ mannan backbone extension is terminated by an $\alpha-1,2$-linked mannose $[29,35,36]$.

Branches of $\alpha-1,2$-linked mannose residues are added to the $\alpha-1,6$-mannan backbone using $\alpha-1,2$-mannosyltransferase Mnn2, and then they are extended by residues of $\alpha-1,2-$ linked mannose using Mnn5. Moreover, five additional proteins: Kre2/Mnt1, Ktr1, Ktr2, Ktr3, and Yur1 participate in the outer chain extension by adding $\alpha$-1, 2-linked mannose residues to the mannan side branches. Finally, the outer chains are terminated by an $\alpha-1,3$-linked mannose, which is added by Mnn1 [35, 36]. Mannan can also be modified using phosphomannose, where Phosphodiester-linked mannoses are associated with $\alpha 1$, 2-linked residues. Mnn6 and Mnn4 transfer Phosphomannoses, and the level of phosphorylation is high at the late log and stationary stage of yeast growth [35]. 


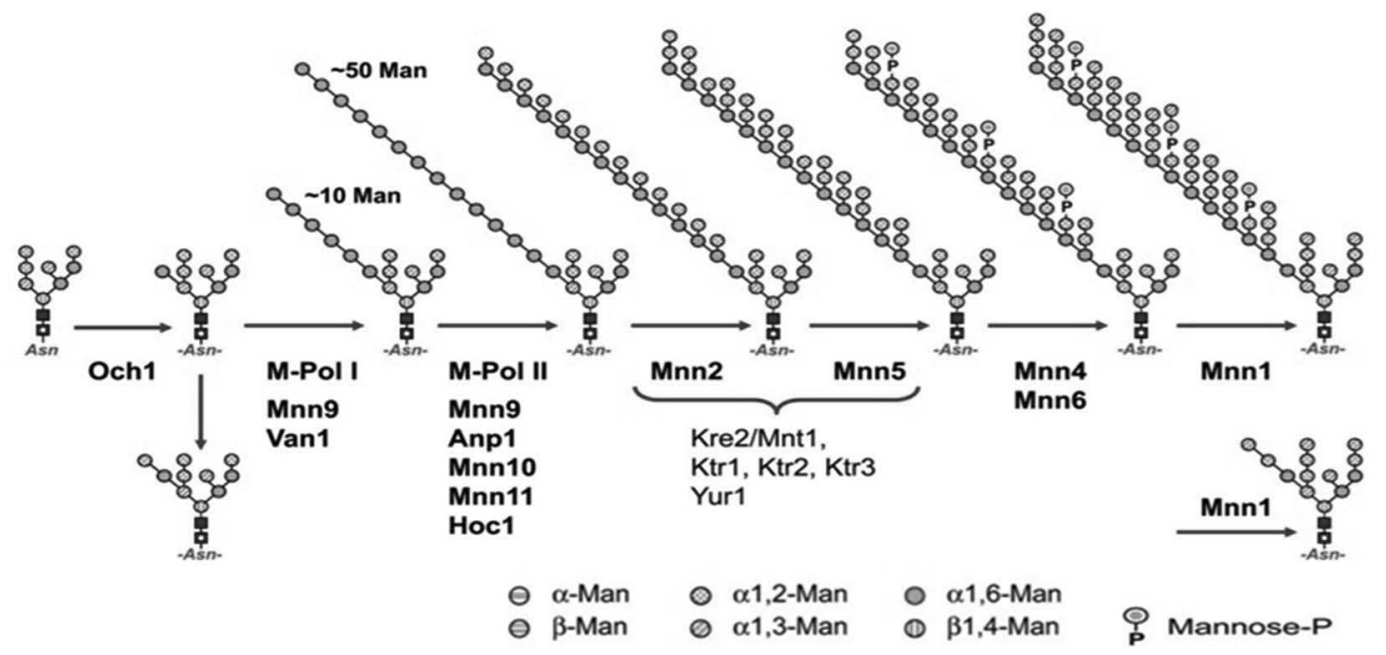

Fig. 3. The modification of N-linked glycans in the Golgi of S. cerevisiae [34]

\subsubsection{O-linked glycosylation}

The O-linked structure consists of a short-chain of 4-5 mannose units attached to serine and threonine. The first two mannan residues are linked by $\alpha-1,2$, and the subsequent ones are linked by $\alpha-1,3$ [38].

The initial step of the O-mannosylation starts in ER, where the first mannosyl residue from Dol-P-Man is transferred onto serine or threonine and attached by $\alpha$-linkage. O-mannosylation is catalyzed by a family of protein O-Mannosyltransferases (PMTs) enzymes. These enzymes participate in the protein O-mannosylation, where they catalyze mannosyl residues' transfer to serine/ threonine [39]. In eukaryotes, PMTs family is divided into PMT1, PMT2, and PMT4 subfamilies, which differ in protein substrate specificity. $S$. cerevisiae has three members of PMT2, two members of PMT1, and one member of PMT4 [40], while in other yeasts and filamentous fungi, there is only one member from each [41, 42].

The extension of serine-linked or threonine-linked mannose structure occurs in the Golgi apparatus, where up to four mannosyl residues are added to this structure using enzymes of the KTR family (Kre2 / Mnt1, Ktr1, and Ktr3) that catalyze $\alpha-1,2$ links and enzymes of the MNN1 family (Mnn1, Mnt2, and Mnt3) that catalyze $\alpha-1,3$ links [39].

In $S$. cerevisiae, O-mannosyl glycan is important for the stability and function of secretory and membrane proteins. Therefore, it plays an important role in cell polarity and cell wall integrity [42].

\section{Methods of Extracting Mannan Oligosaccharides from Yeast}

The yeast cell wall consists of polysaccharides (mannan and $\beta$-glucans), protein, lipids, and a small amount of chitin 1 [5]. It was found that most of the mannan is associated with proteins in the form of mannoprotein complex, which make up $30-40 \%$ of the total cell wall; therefore, the viable extraction of mannan oligosaccharides deserves to be studied along with the necessary deproteinization [4].

The dilute alkali-Sevage method has proven relevant and suitable in the extraction of mannan oligonucleotides.

Extraction is an important method used to obtain the water-soluble mannan oligosaccharides from the yeast cell wall. The mannan was obtained from $5 \mathrm{~g}$ yeast biomass using $50 \mathrm{ml}$ of $1 \% \mathrm{NaOH}$ subjected to $100{ }^{\circ} \mathrm{C}$ for 2 hours. The cooling and neutralizing of the soluble mannan oligosaccharide were done at $\mathrm{pH} 7$ with dilute $\mathrm{HCl}$ solution. The sedimentation of mannan polysaccharide done using $200 \mathrm{ml}$ of absolute ethanol, which was added to it after filtration. Then the sediment was washed with absolute ethanol and diethyl ether, respectively $[5,8]$.

Three main methods work on different principles, including the Sevage (hydrochloric acid) and trichloroacetic acid (TCA) methods are using for deproteinization.

\section{- Sevage method of deproteinization.}

This method involves the addition of isoamyl alcohol ( 0.2 volumes) to concentrated crude mannan oligosaccharide solution in a ratio of 5 to 1 . The mixture was placed in a separatory funnel and shaken for about $5 \mathrm{~min}$. The residual chloroform and aqueous layers were formed, and the chloroform layer was drawn off. The procedure has to be repeated 3-5 times until precipitate at the interface disappears [5].

\section{- TCA Method of Deproteinization.}

TCA Method of Deproteinization involved adjusting the concentrated crude mannan oligosaccharides solution to $\mathrm{pH}$ 3 using a 10\% TCA solution overnight. After the sample's centrifugation for 10 minutes at 5,000 RPM. The resulting precipitate is discarded, thus obtaining a deproteinized solution [44]. The procedure has to be repeated more than once.

\section{- Method of Deproteinization Using Hydrochloric} Acid.

Under this method, the concentrated crude mannan oligosaccharides solution is adjusted to a $\mathrm{pH}$ of 3 using $2 \mathrm{M}$ hydrochloric acid overnight. The solution had to be centrifuged for about ten minutes at 5,000 RPM [43]. The sediment has to be discarded to get the deproteinized solution.

Many studies reported that the percentage of deproteinization was higher using the TCA and hydrochloric acid methods, respectively. While the loss of mannan polysaccharide using the Sevage method was lower compared to the other two methods, and this may be due to more obvious damage to mannan oligosaccharides caused by TCA and hydrochloric acid, respectively $[3,18]$.

In terms of experimental operation and safety, the Savage reagent contains poisonous chloroform, and the process is cumbersome. While the deproteinization using TCA and hydrochloric acid only needs to be adjusted to $\mathrm{pH}$, allowing 
the protein to settle; therefore, these two methods are widely used to remove proteins $[8,18]$.

\section{Conclusion}

Mannan is one of the polysaccharides widely distributed in nature [9]. It enters the formation of hemicellulose in plants, and it is considered the main compound of the cell wall in fungi and yeasts [10,44]. Mannan polysaccharide has many attractive features that led to a focus on its use in many sectors such as medicine and nutrition $[2,3]$.

The yeast cell walls are a very cheap by-product produced in large quantities by the yeast-extract producing sector and consists mainly of alkali-soluble mannoprotein compounds $[1,2]$. In this context, using the yeast cell wall as a source for obtaining mannan has been the focus of many researchers' attention [1].

Numerous studies have proven that the optimum conditions for obtaining mannan were at a temperature of 100 by using a $1 \%$ sodium hydroxide $(\mathrm{NaOH})$ solution for 2 hours [2].

The use of TCA and hydrochloric acid for deproteinization showed a greater loss of mannan polysaccharide than the Sevage method. This is due to the damage caused by the effect of these acids on mannan [3]. Despite the loss of mannan polysaccharides, the Sevage method is less popular than the other two methods because it is cumbersome and is not safe because the Sevage reagent contains toxic chloroform [2].

\section{References}

1. Liu Y., Huang G., Lv M. Extraction, characterization and antioxidant activities of mannan from yeast cell wall. Int $J$ Biol Macromol. 2018; S0141-8130 (18):31953-6. doi:10.1016/j. ijbiomac. 2018.06.145.

2. Yamabhai M., Sak-Ubol S., Srila W., Haltrich D. Mannan biotechnology: From biofuels to health. Crit Rev Biotechnol. 2016;36 (1):32-42. doi:10.3109/07388551.2014.923372.

3. Huang G. L., Yang Q., Wang Z. B. Extraction and deproteinization of mannan oligosaccharides. Zeitschrift fur NaturforschSect C J Biosci. 2010;65 C (5-6): 387-390. doi:10.1515/znc2010-5-611

4. Maru V., Hewale S., Mantri H., Ranade V. Partial Purification and Characterization of Mannan Oligosaccharides from Cell Wall of Saccharomyces cerevisiae. Int J Curr Microbiol Appl Sci. 2015;4 (12):705-711.

5. Huang G. L. Extraction of two active polysaccharides from the yeast cell wall. Zeitschrift fur Naturforsch - Sect C J Biosci. 2008; 63 (11-12):919-921. doi:10.1515/znc-2008-11-1224.

6. Hooge D. M., Kiers A., Connolly A. Meta-analysis summary of broiler chicken trials with dietary Actigen ${ }^{\circledR}$ (2009-2011). Int. J. Poultry Sci. 2013; 12: 1-8.

7. Spring P., Wenk C., Connolly A., Kiers A. A review of 733 published trials on Bio-Mos ${ }^{\circledR}$, a mannan oligosaccharide, and Actigen ${ }^{\circledR}$, a second generation mannose rich fraction, on farm and companion animals. Journal of Applied Animal Nutrition. 2015; $3: 1-11$.

8. Al-Manhel A. J., Niamah A. K. Mannan extract from Saccharomyces cerevisiae used as prebiotic in bioyogurt production from buffalo milk. Int Food Res J. 2017;24 (5):2259-2264.

9. Scheller HV, Ulvskov P. Hemicelluloses. Annu. Rev. Plant Biol. 2010; (61): 263-89.

10. Leroux O., Leroux F., Bagniewska-Zadworna A., Knox J. P., Claeys M., Bals S., Viane R. L. Ultrastructure and composition of cell wall appositions in the roots of Asplenium (Polypodiales). Micron.2011; (42):863-870.

11. Moreira L. R., Filho E. X. An overview of mannan structure and mannan-degrading enzyme systems. Appl Microbiol Biotechnol. 2008; (79): 165-78.

12. Dunn E. K., Shoue D. A., Huang X., et al. Spectroscopic and Biochemical Analysis of Regions of the Cell Wall of the Unicellular «Mannan Weed', Acetabularia acetabulum. 2007; 48 (1): 122-133. doi:10.1093/pcp/pc1053

13. Graus M. S., Wester M. J., Lowman D. W., et al. Mannan Molecular Substructures Control Nanoscale Glucan Exposure in Candida Article Mannan Molecular Substructures Control Nanoscale Glucan Exposure in Candida. CellReports. 2018;24 (9):2432-2442. e5. doi:10.1016/j. celrep. 2018.07.088

14. Farka V., Bauer S. Biosynthesis of yeast mannan. Characterization of mannan-synthesizing enzyme systems from mutants defective in mannan structure. 1976; (21):459-464. doi:10.1007/ BF02876937

15. Shibata N., Kobayashi H., Suzuki S. Immunochemistry of pathogenic yeast, Candida species, focusing on mannan. Proceeding of Japan Academy Ser B Physical and Biological Sciences. 2012;88 (6) 250-265.

16. Chae H. J., Joo H., \& In M. J. Utilization of brewer's yeast cells for the production of food-grade yeast extract. Part 1: effects of different enzymatic treatments on solid and protein recovery and flavor characteristics. Bioresource technology, 2001. 76 (3), 253-258.

17. Moreno I., Tutrone N., Sentandreu R., Valentín E. Saccharomyces cerevisiae Rds2 transcription factor involvement in cell wall composition and architecture. Int Microbiol. 2008;11 (1):57-63. doi:10.2436/20.1501.01.45.

18. Harbah R., Agembo E. O., Meledina T. V., Kritchenkov A. S., Ivanova V. A. Extraction of crude Mannan oligosaccharides from yeast and their uses // Вестник Международной академии холода. 2020. № 1. C. 46-51. [Harbah R., Agembo E. O., Meledina T. V., Kritchenkov A. S., Ivanova V. A. Extraction of crude Mannan oligosaccharides from yeast and their uses. Journal of International Academy of Refrigeration. 2020. No 1. p. 46-51. (in Russian)]

19. Pavlova K., Panchev I., Hristozova T. Physico-chemical characterization of exo-mannan from Rhodotorula acheniorum MC. World Journal of Microbiology \& Biotechnology. 2005; 21 279-283.

20. Poli A., Anzelmo G., Tommonaro G., Pavlova K., Casaburi A., Nicolaus B. Production and chemical characterization of an exopolysaccharide synthesized by psychro-philic yeast strain Sporobolomyces salmonicolor AL1 isolated from Livingston Island, Antarctica. Folia Microbiologica 2011;55 (6) 576.

21. Corsaro M. M., Evidente A., Lanzetta R., Lavermicocca P., Molinaro A. Structural determination of the phytotoxic mannan exopolysaccharide from Pseudomonas syringae pv. Ciccaronei. Carbohydr Res. 2001 Jan 30;330 (2):271-7.

22. Guo S., Mao W., Han Y., Zhang X., Yang C. Bioresource Technology Structural characteristics and antioxidant activities of the extracellular polysaccharides produced by marine bacterium Edwardsiella tarda. Bioresour Technol. 2010;101 (12):4729-4732. doi:10.1016/j. biortech. 2010.01.125

23. Moreira L., Ximenes E., Filho F. An overview of mannan structure and mannan-degrading enzyme systems. Appl Microbiol Biotechnol.2008; (79):165-178. doi:10.1007/s00253-008-1423-4

24. Cui S. W., Wu Y., Ding H. The range of dietary fibre ingredients and a comparison of their technical functionality. Woodhead Publishing Series in Food Science, Technology and Nutrition. 2013; 96-119. doi:10.1533/9780857095787.1.96 
25. Steinbach W. J. Principles and Practice of Pediatric Infectious Diseases $4^{\text {th }}$ Edition. Part III. 244 -Aspergillus Species. 2012; 1203-1209. e4 (https://www.sciencedirect.com/science/article/ pii/B9781437727029002464)

26. Srinivasan K. Fenugreek (Trigonella foenum-graecum): A Review. Food Reviews International.2015; 22 (2):203-224. doi:10.1080/87559120600586315

27. Polari L., Ojansivu P., Makela S., Eckerman C., Holmbom B., Salminen S. Galactoglucomannan Extracted from Spruce (Picea abies) as a Carbohydrate Source for Probiotic Bacteria. Agric. Food Chem. 2012; (60):11037-11043.

28. Faber T. A., Hopkins A. C., Middelbos I. S., Price N. P. J., Fahey G. C. Galactoglucomannan oligosaccharide supplementation affects nutrient digestibility, fermentation end-product production, and large bowel microbiota of the dog. Journal of Animal Science. 2011; 89 (1):103-12

29. Jungmann J., Rayner J. C., Munro S. The Saccharomyces cerevisiae Protein Mnn10 p / Bed1 p Is a Subunit of a Golgi Mannosyltransferase Complex The Saccharomyces cerevisiae Protein Mnn10 p / Bed1 p Is a Subunit of a Golgi Mannosyltransferase Complex*. 2017; (February). doi:10.1074/ jbc. 274.10 .6579

30. Dunn E. K., Shoue D. A., Huang X., et al. Spectroscopic and Biochemical Analysis of Regions of the Cell Wall of the Unicellular «Mannan Weed', Acetabularia acetabulum. 2007;48 (1):122-133. doi:10.1093/pcp/pcl053

31. Farka V., Vagabov V. M., Bauer S. Biosynthesis of yeast mannan diversity of mannosyltransferases in the mannan-synthesizing enzyme system from yeast. Biochimica et Biophysica Acta. 1976; 428: 573-582

32. Ruddock L. W., Molinari M. N-glycan processing in ER quality control. Journal of Cell Science. 2006;119:4373-4380. doi:10.1242/jcs. 03225

33. Araki K., Nagata K. Protein Folding and Quality Control in the ER. Cold Spring Harbor Perspectives in Biology.2014;3: a007526. doi:10.1101/cshperspect. a007526

34. Signaling C., Orlean P. Architecture and Biosynthesis of the Saccharomyces cerevisiae Cell Wall. 2012;192 (November): 775-818. doi:10.1534/genetics. 112.144485

\section{Сведения об авторах}

\section{Харба Разан}

Аспирант факультета биотехнологий Университета ИТМО, 191002, Санкт-Петербург, ул. Ломоносова, 9

\section{Меледина Татьяна Викторовна}

Д. т. н., профессор факультета биотехнологий Университета ИТМО, 191002, Санкт-Петербург, ул. Ломоносова, 9, SPIN-код: 5771-8409, Author ID: 381606,

tatiana.meledina@yandex.ru

\section{Маньшин Дмитрий Викторович}

Магистрант, инженер факультета биотехнологий Университета ИТМО, 191002, Санкт-Петербург, ул. Ломоносова, 9, dvmanshin@itmo.ru

\section{Андреев Василий Валерьевич}

Инженер-микробиолог, ООО «Пивоваренная компания «Балтика», 194292, Санкт-Петербург, 6-й Верхний пер., 3, andreev@baltika.com
35. Lesage G., Bussey H. Cell Wall Assembly in Saccharomyces cerevisiae. Microbiol Mol Biol Rev. 2006;70 (2):317-343. doi:10.1128/mmbr. 00038-05

36. Bar-peled M., Neill M. A. O. Plant Nucleotide Sugar Formation, Interconversion, and Salvage by Sugar. Plant Biol. 2011;62:127155. doi:10.1146/annurevarplant-042110-103918

37. Liu M., Borgert A., Barany G., Live D. Conformational Consequences of Protein Glycosylation: Preparation of O- Mannosyl Serine and Threonine building blocks and their incorporation into glycopeptide sequences derived from $\alpha$-Dystroglycan. J. Pept. Sci. 2008; 90: 358-368.

38. Loibl M., Strahl S. Protein O-mannosylation: What we have learned from baker's yeast. Biochim Biophys Acta - Mol Cell Res. 2013;1833 (11):2438-2446.

39. Gentzsch M., Tanner W. The PMT gene family: protein O-glycosylation in Saccharomyces cerevisiae is vital. EMBO J. 1996; 15: 5752-5759.

40. Lehle L., Strahl S., Tanner W. Protein glycosylation, conserved from yeast to man: a model organism helps elucidate congenital human diseases, Angew. Chem. Int. Ed Engl. 2006; 45:6802-6818.

41. Mouyna I., Kniemeyer O., Jank T., Loussert C., Mellado E., Aimanianda V., Beauvais A., Wartenberg D., Sarfati J., Bayry J., Prevost C. M., Brakhage A. A., Strahl S., Huerre M., Latge P. J. Members of protein O-mannosyltransferase family in Aspergillus fumigatus differentially affect growth, morphogenesis and viability, Mol. Microbiol. 2010;76:1205-1221.

42. Yang Y. H., Tatebayashi K., Yamamoto K., Saito H. Glycosylation defects activate filamentous growth Kss1 MAPK and inhibit osmoregulatory. Hogl MAPK, EMBO J. 2009;28: 1380-1391.

43. Yamabhai M., Sak-Ubol S., Srila W., \& Haltrich D. Mannan biotechnology: from biofuels to health. Critical Review in Biotechnology, 2013. 1-11.

44. Bzducha-Wro’bel A., Kieliszek M., \& Błazejak S. Chemical composition of the cell wall of probiotic and brewer's yeast in response to cultivation medium with glycerol as a carbon source. Eur Food Res Technol. 2013. 237, 489-499.

45. Yeoman R. I., Honey Dad, Schroeder C. M., Mackie R. I., \& Can I. K. O. Chapter 1. Thermostable Enzymes as Biocatalysts in the Biofuel Industry. 2010;70:1-55.

\section{Information about authors}

\section{Harbah Razan}

Graduate student of the Faculty of BioTech of ITMO University, 191002, Russia, St. Petersburg, Lomonosov str., 9

\section{Meledina Tatyana V.}

D. Sc., Professor of the Faculty of BioTech of ITMO University, 191002, Russia, St. Petersburg, Lomonosov str., 9, SPIN-код: 5771-8409, Author ID: 381606, tatiana.meledina@yandex.ru

\section{Manshin Dmitry V.}

Undergraduate, Engineer of the Faculty of BioTech of ITMO University, 191002, Russia, St. Petersburg, Lomonosov str., 9, dvmanshin@itmo.ru

\section{Andreev Vasilii V.}

Microbiologist Engineer, Baltika Breweries, Russia, 194292,

Saint Petersburg, 6th Upper lane, 3,

andreev@baltika.com 